\title{
FAJLAGOS FORGÁCSOLÓ ERŐ SZERKEZETFÜGGŐSÉGE
}

\section{THE SPECIFIC CUTTING FORCE AS A FUNCTION OF THE MICROSTRUCTURE}

\author{
Varga Péter ${ }^{1}$, Horváth Richárd ${ }^{2}$, Oláh Ferenc ${ }^{3}$, Lozsek Martin ${ }^{4}$ \\ ${ }^{1234}$ Óbudai Egyetem Bánki Donát Gépész és Biztonságtechnikai Mérnöki Kar, \\ Anyagtudományi és Gyártástechnológiai Intézet, H-1081, Magyarország, Budapest, \\ Népszínház utca, 8. \\ ${ }^{1}$ varga.peter@bgk.uni-obuda.hu; ${ }^{2}$ horvath.richard@bgk.uni-obuda.hu; \\ ${ }^{3}$ illogicalferi@gmail.com; ${ }^{4}$ martin.lozsek@gmail.com
}

\begin{abstract}
One of the most important parameter in cutting is the cutting force and the ratio of the components of the force. The ratio of the main force component and the chip's cross-section is the so-called specific cutting force. The specific cutting force is closely linked to the mechanical properties of the material such as the tensile strength and hardness. This paper discusses the dependence of the specific cutting force on the microstructure of the material. Two kind of specimens are examined which have the same chemical composition and hardness but different microstructure - due to different heat treatment.
\end{abstract}

Keywords: heat treatment, microstructure, turning, cutting force measuring, specific cutting force.

\section{Összefoglalás}

Az anyagok forgácsolhatóságának egyik jellemzője a forgácsoláskor fellépő erőhatások nagysága és aránya. A forgácsoláskor fellépő erőhatás és a deformálatlan forgácskeresztmetszet hányadosát fajlagos forgácsoló erőnek nevezik, mely értékkel jellemezhetőek a forgácsolandó anyagok. A fajlagos forgácsoló erö értéke szoros kapcsolatban áll a munkadarab mechanikai tulajdonságaival (pl.: keménység, szakítószilárdság). Ez a publikáció, mechanikai tulajdonságokban összehasonlítható, azonos öszszetételü, de - eltérö hőkezelési állapotuknak köszönhetően - különböző szövetszerkezettel rendelkező acél alapanyag fajlagos forgácsoló erő vizsgálatát mutatja be.

Kulcsszavak: hökezelés, szövetszerkezet, esztergálás, forgácsoló erömérés, fajlagos forgácsoló erö.

\section{Bevezetés}

Bizonyított, hogy a szövetszerkezettöl nagyban függnek a mechanikai tulajdonságok. Az anyagok egyik fontos forgácsolhatósági tulajdonsága a forgácsoló erő igényük, melyet az alábbi módon tudunk meghatározni:

$$
F=k \cdot A
$$

ahol az $A, \mathrm{~mm}^{2}$ a deformálatlan forgács keresztmetszet, a $k, \mathrm{~N} / \mathrm{mm}^{2}$ pedig a fajlagos forgácsoló erő, melyet alapvetően a keménységgel és a szakítószilárdsággal hoznak kapcsolatba [1]. Ezeket az értékeket a szerszámkatalógusok is használják, olyan módon, hogy a $k$ értékeit bizonyos intervallumban egy adott betüjellel (forgácsolandó anyag típusok) jelölik. Az 1. ábra egy ilyenre mutat példát. 


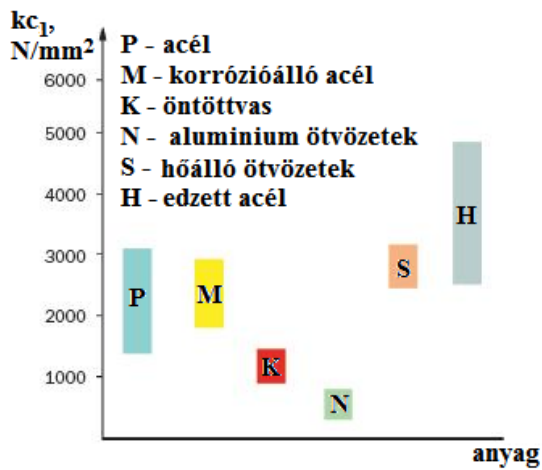

1. ábra. Fajlagos forgácsoló erö értékek (k) forgácsolandó anyagtípusok szerint [2 alapján]

Sok kutatás foglalkozik a különböző alapanyagok forgácsolhatóságával, forgácsolási erő igényeivel.

AISI 4340 acél erőtani viszonyait vizsgálták Suresh és társai [3] esztergálásnál. Vizsgálataikat bevonatos keményfém szerszámmal végezték. Lineáris egyenleteket építettek a forgácsoló erő eredője és a fajlagos forgácsoló erő számítására. Megállapították, hogy a forgácsoló erőre és a fajlagos forgácsoló erőre legnagyobb hatással az elötolás van, ezt követi a fogásmélység, majd a forgácsolási sebesség.

Rao és társai [4] AISI 1050 acél esztergálását vizsgálták, kerámia szerszámmal. Vizsgálataikat a felületi érdesség vizsgálatára és a forgácsolás erőtani viszonyaira terjesztették ki. Empirikus modelleket alkottak mind az érdesség mind a forgácsoló erök becslésére, és megállapították, hogy az elötolásnak szignifikáns hatása van mind a forgácsoló erőre, mint a felületi érdességre. A forgácsolási sebesség sem a kialakult érdességre sem a forgácsoló erőre nem volt számottevő hatással, a fogásmélység pedig csak a forgácsoló erőt befolyásolta.

$\mathrm{Az}$ anyagok fajlagos forgácsoló erejének függése kizárólag a keménységtől és/vagy a szakítószilárdságtól véleményünk szerint nem egzakt megközelítés, hiszen azonos mechanikai tulajdonságok (kemény- ség, szakítószilárdság) eltérő szövetszerkezetekkel is elérhetöek [5].

E cikkben annak a kísérletsorozatnak az eredményeit mutatjuk be, mely arra keresi a választ, hogyan alakul a fajlagos forgácsoló erő igény, azonos kémiai összetételü és keménységü, ám különböző szövetszerkezetü acél esztergálásakor.

\section{Anyag és módszer}

\subsection{Acélminőség}

A vizsgálatokat 34CrNiMo6 nemesíthető acél próbatesteken végetzük, melynek összetétele az 1.-es táblázatban található.

1. táblázat. 34CrNiMo6 összetétel

\begin{tabular}{|c|c|c|c|c|c|}
\hline $\mathrm{C}$ & $\mathrm{Si}$ & $\mathrm{Mn}$ & $\mathrm{Cr}$ & $\mathrm{Mo}$ & $\mathrm{Ni}$ \\
\hline $0,3-$ & $\max$. & $0,5-$ & $1,3-$ & $0,15-$ & $1,3-$ \\
0,38 & 0,4 & 0,8 & 1,7 & 0,3 & 1,7 \\
\hline
\end{tabular}

\subsection{Az alkalmazott hőkezelések}

A hőkezelési eljárások során azonos keménységü szövetek létrehozása volt a cél, melyek különbözőképp keletkeztek. Hülés során bénit, hevítéssel szferoidit jött létre. A hőkezelési ciklusok a 2-es ábrán láthatók.

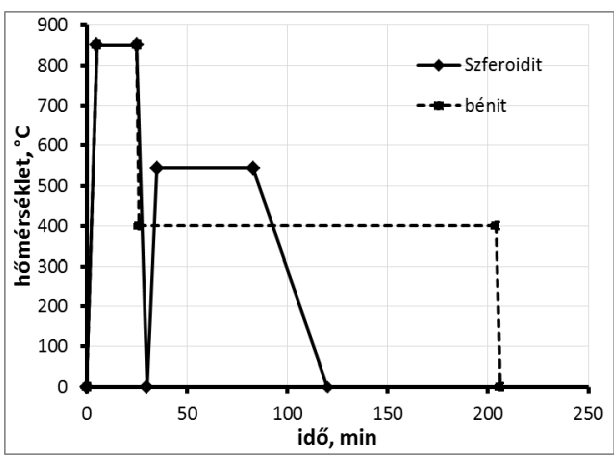

2. ábra. Hökezelési diagramok

- A szferoidites szövetszerkezet létrehozását úgy értük el, hogy $850{ }^{\circ} \mathrm{C}$-on hőn tartottuk 20 percig a darabokat, azután olajban hütöttük (ezzel elérve a martenzites szövetszerkezetet, $575 \pm 3$ HV), majd $545^{\circ} \mathrm{C}$-on egy órán keresztül megeresztettük és levegőn hütöttük. 
- A bénites szövetszerkezetet hasonlóan $850{ }^{\circ} \mathrm{C}$-on hön tartottuk, majd izotermásan hütöttük $400{ }^{\circ} \mathrm{C}$-os sófürdőben három órán keresztül.

\subsection{Az eltérő szövetszerkezetű acélok (34CrNiMo6) szilárdsági tulajdonsá- gának vizsgálata}

A hőkezelések után minden munkadarabon keménységmérést végeztünk 3 alkalommal. A mért keménységek (szövetszerkezetenként $12 \mathrm{db}$ mérés) átlaga és szórása az 1. táblázatban található.

1. táblázat. Keménységmérés eredményei

\begin{tabular}{|c|c|c|}
\hline Szövetszerkezet & HV átlag & $\mathrm{S}_{\mathrm{HV}}$ \\
\hline Bénit & 364 & 3,92 \\
\hline Szferoidit & 369 & 3,60 \\
\hline
\end{tabular}

Az 1. táblázatból látható, hogy különböző szövetszerkezeteknél sikerült közel megegyező keménységet előállítani.

\subsection{Forgácsoló erő mérés}

A forgácsolási erőmérés egy speciálisan átalakított esztergakésszárból (PDLNR 2525M 11) lett átalakítva, oly módon, hogy a lapka alá egy KISTLER 9251A 3 komponenses erőmérö lett beépítve (3. ábra) [6].

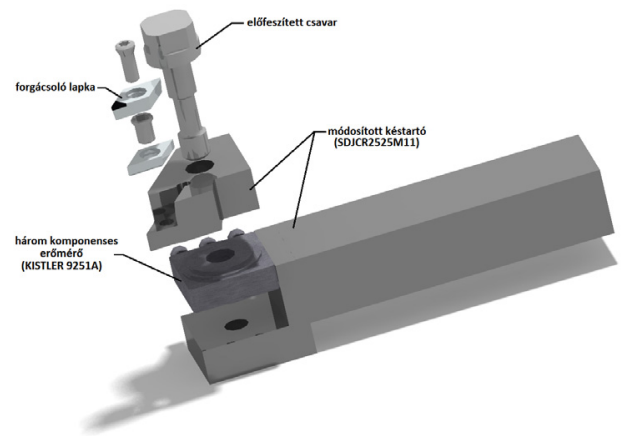

3. ábra Erömérésre átalakitott eszterga késszár

A forgácsoláshoz használt bevonatos keményfém lapka kódja: DCMT 11T304-53 (Sandvik).

A forgácsolási kísérleteket úgy végeztük, hogy a forgácsoló sebességet, melynek hatása a legkisebb a forgácsoló erőre $[7,8,9]$ $v_{c}=100 \mathrm{~m} / \mathrm{min}$, valamint a fogásvételt $a=$ $0,5 \mathrm{~mm}$ konstans értéken tartottuk, míg 8 szinten változtattuk az előtolás értékét $f=$ 0,03-0,17 mm.

\section{Eredmények}

A forgácsolási kísérleteket mindkét szövetszerkezetủ acélnál azonos körülmények között végeztük. A kísérletek elrendezésének felülnézeti képét mutatja a 4. ábra.

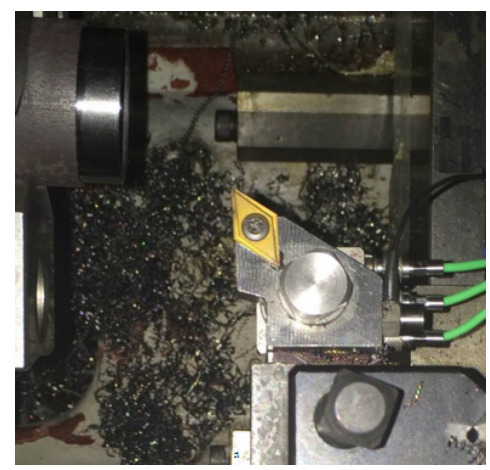

4. ábra Forgácsolási kísérletek elrendezése

A kísérleti beállításokat, és a fő forgácsoló erő valamint a hozzá tartotó fajlagos forgácsoló erő értékét a 2. táblázat tartalmazza.

2. táblázat. Kisérleti beállitások eredményei

\begin{tabular}{|r|c|c|c|c|c|c|}
\hline $\begin{array}{c}\text { Mérés } \\
\mathrm{i} \\
\text { ponto } \\
\mathrm{k}\end{array}$ & $\mathrm{f}, \mathrm{mm}$ & $\begin{array}{c}\mathrm{A}, \\
\mathrm{mm}^{2}\end{array}$ & $\begin{array}{c}\mathrm{F}_{\mathrm{c}} \\
\text { bénit, } \\
\mathrm{N}\end{array}$ & $\begin{array}{c}\mathrm{k}_{\mathrm{c}} \text { bénit, } \\
\mathrm{N} / \mathrm{mm}^{2}\end{array}$ & $\begin{array}{c}\mathrm{F}_{\mathrm{c}} \\
\text { szferoidi } \\
\mathrm{t}, \mathrm{N}\end{array}$ & $\begin{array}{c}\mathrm{k}_{\mathrm{c}} \\
\text { szferoid } \\
\mathrm{it} \\
\mathrm{N} / \mathrm{mm}^{2}\end{array}$ \\
\hline 1. & 0,03 & 0,015 & 84 & 5573,3 & 147 & 9800,00 \\
\hline 2. & 0,05 & 0,025 & 116 & 4620,0 & 171 & 6840,00 \\
\hline 3. & 0,07 & 0,035 & 145 & 4142,9 & 188 & 5371,43 \\
\hline 4. & 0,09 & 0,045 & 167 & 3715,6 & 222 & 4933,33 \\
\hline 5. & 0,11 & 0,055 & 200 & 3636,4 & 246 & 4472,73 \\
\hline 6. & 0,13 & 0,065 & 221 & 3400,0 & 277 & 4261,54 \\
\hline 7. & 0,15 & 0,075 & 244 & 3253,3 & 291 & 3880,00 \\
\hline 8. & 0,17 & 0,085 & 270 & 3176,5 & 324 & 3811,76 \\
\hline
\end{tabular}

Az eredményekből jól látható, hogy a bénites szövetủ anyag föforgácsoló erő igénye kisebb a szferoiditesnél, melyeknek szignifikáns különbségét páros t-próbával ellenőriztük (5. ábra). 


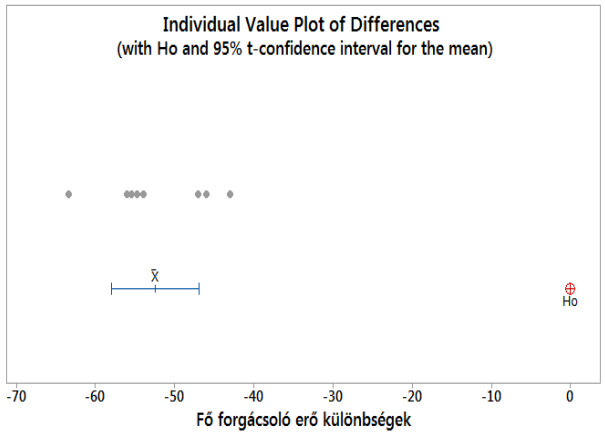

5. ábra. A fö forgácsoló erök összehasonlitása páros t-próbával

Az ekvivalens forgácsvastagság [10] függvényében logaritmikus léptékben vizsgálva a fajlagos forgácsoló erô igényét a vizsgált daraboknak, szintén megállapítható az előbb említett különbözőség (6 ábra).

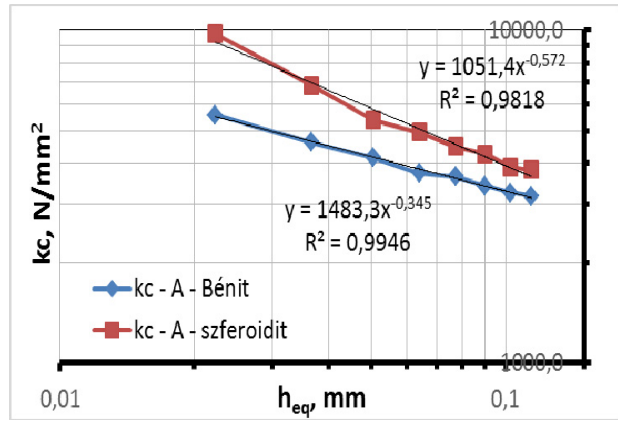

6. ábra. A fajlagos forgácsoló erök az ekvivalens forgácsvastagság függvényében.

\section{Következtetések}

Az elvégezett kísérletek célja volt azonos keménységü, de eltérő szövetszerkezetü acélok forgácsolhatóságainak vizsgálat a fö forgácsoló erő komponens, valamint a fajlagos forgácsoló erő értékek elemzésével. Ennek érdekében eltérő hőkezeléssel létrehoztunk azonos keménységü, de eltérő szövetszerkezetü próbadarabokat (bénit, szferoidit), majd elvégeztük ezek forgácsolási kísérleteit, melyekből az alábbiak állapíthatóak meg:
- A forgácsolhatóságot nagyban jellemző fajlagos forgácsoló erő jelentős különbözőséget mutat azonos összetételü, keménységü, de eltérő szövetszerkezetü acélok esetén;

- a bénites szövetű acél fajlagos forgácsoló erő igénye számottevően kisebb, melyet páros t-próbával igazoltunk.

\section{Szakirodalmi hivatkozások}

[1] Smith, G.T.: Cutting Tool Technology, (Springer-Verlag London, 2008)

[2] Corokey 2010 szerszámkatalógus (Sandvik)

[3] Suresh, R., Basavarajappa, S., Samuel, G.L.: Some studies on hard turning of AISI 4340 steel using multilayer coated carbide tool, Measurement 45, 2012, 1872-1884.

[4] Rao, C.J., Rao, D.N., Srihari, P.: Influence of cutting parameters on cutting force and surface finish in turning operation, Procedia Engineering 64, 2013, 1405 - 1415.

[5] Barta, I., Kovács, T., Borossay, B.: Adott szerkezetü próbatestek előállítása, XII. Fiatal Müszakiak Tudományos Ülésszaka, Koloszvár 2007, 27-30.

[6] Horvath, R.. Palinkas, T., Matyasi. Gy., Dregelyi-Kiss, A.: The design, calibration and adaption of a dynamometer for fine turning, International Journal of Machining and Machinability of Materials (in print)

[7] Aouici, H., Yallese, M.A., Chaoui, K., Mabrouki, T., Rigal, J.-F.: Analysis of surface roughness and cutting force components in hard turning with CBN tool: Prediction model and cutting conditions optimization, Measurement 45 (2012) 344-353

[8] Lalwani, D.I., Mehta, N.K., Jain, P.K.: Experimental investigations of cutting parameters influence on cutting forces and surface roughness in finish hard turning of MDN250 steel, Journal of materials processing technology 206 (2008) 167-179.

[9] Fetecau, C., Stan F.: Study of cutting force and surface roughness in the turning of polytetrafluoroethylene composites with a polycrystalline diamond tool, Measurement 45 (2012) 1367-1379.

[10] Horváth, R., Sipos, S., Mátyási, Gy.,: Új erömodell finomesztergálás esetén, GÉP 6-7, (2014) 50-55. 